\title{
縦隔リンパ節の領域自動抽出と手術支援のための肺区域表示
}

\author{
田中悠子 1 ・田中啓介 ${ }^{2}$ ・上甲 剛 3 ・ \\ 渡辺俊一 4 ・楠本昌彦 $5 \cdot$ 土屋了介 4
}

要旨一一近年, マルチスライス CT の開発により短時間に鮮明な肺野情報を得ることが可能になった。 これに伴 い, 肺野内構造物を解析するアルゴリズムもより発展している. 現在我々は, 肺領域のマルチスライス CT 画像を用い

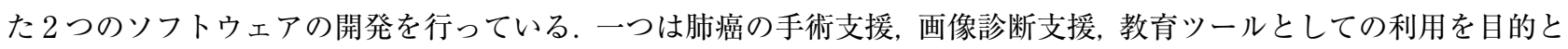
した, 胸部造影 CT 画像を用いた縦隔リンパ節の領域抽出を行うソフトウェアであり, もう一つは, 肺癌術前シミュ レーション, 教育ツールとしての利用を目的とした, 肺区域表示を行うソフトウェアである. 本稿においてはこれらソ フトウェアの概要について報告し，今後の展望についても述べる（肺癌. 2008;48:754-758）

索引用語——肺癌, 縦隔リンパ節, 肺区域, マルチスライス CT

\section{The Segmentation of Mediastinal Lymph Node Stations and Pulmonary Segments}

\author{
Yuko Tanaka1; Keisuke Tanaka²; Takeshi Johkoh'; \\ Shun-ichi Watanabe ${ }^{4}$; Masahiko Kusumoto ${ }^{5}$; Ryosuke Tsuchiya ${ }^{4}$
}

\begin{abstract}
Multi-slice helical CT technology can provide exact information about the chest structure in a single scanning of procedure. Therefore, development of the algorithm that analyzes lung internal-organs has also been developed. In this review, we present two newly developed software programs using multi-slice CT images and its limitations. The first one is for the segmentation of mediastinal lymph node stations from contrast-enhanced chest CT scans which was useful for evaluation of the effects for various therapies, surgical planning, educational tool and diagnostic imaging. The second one is for the segmentation of pulmonary segments which was used before lung operation for small lung cancers. (JJLC. 2008;48:754-758)
\end{abstract}

KEY WORDS — Lung cancer, Mediastinal lymph node, Pulmonary segments, Multi-slice CT

はじめに

本邦に打ける原発性肺癌死亡者数は年々増加傾向にあ り，2003 年には 55000 人と全悪性腫瘍死の約 $18 \%$ を占 め, 悪性腫瘍に伴う男性の死因の第 1 位となっている. ${ }^{1}$
今後 2010 年には肺癌による死亡数が約 10 万人を超える と予測する報告もある. 2 原発性肺癌は非小細胞肺癌と 小細胞肺癌に大別され, 本邦では非小細胞肺癌が, 肺癌 の約 80〜85\% を占める. 1960 年 $\mathrm{Cahan}^{3}$ が 48 例の肺葉 切除成功例を報告し, 以後肺葉切除術が原発性肺癌に対

School of Medicine, Japan; 3Department of Radiology, Kinki Central Hospital of Mutual Aid Association of Public School Teachers, Japan; ${ }^{4}$ Division of Thoracic Surgery, ${ }^{5}$ Division of Radiology, National Cancer Center Hospital, Japan.

Reprints: Yuko Tanaka, Department of Diagnostic and Interventional Radiology, Osaka University Graduate School of Medicine, 22 Yamadaoka, Suita-shi, Osaka 565-0871, Japan(e-mail: y-tanaka@ radiol.med.osaka-u.ac.jp).

(C) 2008 The Japan Lung Cancer Society 
する標準手術として定着し，本邦では肺葉切除術＋肺 門・縦隔リンパ節郭清が推奨されている. ${ }^{4,5}$

近年 CT 装置の進歩により，詳細な肺野領域の情報が 得られるようになったが, マルチスライス CT を用いて, 最小スライス厚である $0.5 \mathrm{~mm}$ で全肺を撮影すると，画 像枚数は 600 枚程度に及び，その情報量は膨大である. また, 肺野領域には肺, 肺動脈, 気管一気管支, 縦隔り ンパ節といった構造物が重なり合い,これらの三次元的 な位置関係を二次元の CT 画像のみから正確に把握する ことは困難である.これに伴い, CT 画像から得られる情 報をより臨床に役立つものとして提供するため, 肺野領 域の構造物の自動抽出や, 領域分け6-8 など多くの手術支 援・診断支援アルゴリズムが提唱されている.

今回我々は, 縦隔リンパ節と肺区域に着目し, 肺癌治 療における手術支援, 画像診断支援, 教育ツールとして の利用を目的とした縦隔リンパ節領域分けと肺区域領域 分けを行うソフトウェアを開発した. 本稿ではこれら 2 つのソフトウェアの概要と今後の展開について述べる.

\section{縦隔リンパ節領域分けソフトウェア}

\section{i) 利用目的}

縦隔リンパ節郭清では, 縦隔内構造物を基に領域分け された一定領域 (compartment) が郭清される. 5 リンパ 節郭清の予後への影響については未だ統一的な見解は示 されてはいないが, 肺癌の病期の決定には重要とされて いる. しかし, CT 画像上の統一的なリンパ節領域の指標 はないとの報告もある. ${ }^{9}$ 確かに, リンパ節領域の指標と して広く用いられている Mountain 分類10 N Naruke 分 類11 は,リンパ節自体を図示したものであり, 縦隔リンパ 節郭清で実際に郭清される一定領域を表示してはいな い. また肺癌取扱い規約 (第 6 版) 12 には CT 読影ガイド ラインとして縦隔リンパ節領域図が示されているが, 三 次元的な画像は示されていない. 診療に関わる者が対象 となるリンパ節領域に対して共通認識を持つためには, 画像上で三次元的に，また実際の CT 画像に重ね合わせ た形で縦隔リンパ節領域を表示することが手助けになる と思われる。

ii）ソフトウェア概要

本ソフトウェアは, 縦隔リンパ節を含んだ縦隔領域を 肺癌取扱い規約（第 6 版）12 に示される「CT 像の縦隔リ ンパ節部位と評価に用いる基本線」にもとづいて\#1〜 \# 7 と\#3a, \#3p の計 9 つの縦隔リンパ節領域毎に領域 分けを行うものである. 入力データには全肺造影 CT 画 像を用い, Virtual Place (ver.1, MI Laboratories, Tokyo, Japan）のプラグインとして Visual Studio 6.0 C ++ (Microsoft Corporation) により開発した.

処理の概要は以下の通りである。 まず, 縦隔領域と境
界面の指標となる大動脈弓, 大静脈を, マニュアル操作 を含んだ閾值処理と連結成分抽出処理により抽出する. 続いて, たとえば上縦隔リンパ節領域（\#1）の下縁とな る「左腕頭静脈と気管正中線が交差する高さ」のような, 各領域の上縁と下縁の指標となる境界面 12 を, 操作者が CTアキシャル断面像を観察することで設定する．最後 に,「大動脈左側線」のような構造物に沿った境界面 12 を, 抽出した大動脈や大静脈領域に沿って自動的に作成, も しくはいくつかの解剖学的特徵点を設定することで作成 する，作成した境界面を用いて，縦隔内構造物の位置関 係を考慮しながら縦隔リンパ節領域毎にラベル付けを行 い, 領域分け表示したものを Figure 1 に示す.

\section{iii）現状と今後の展望}

リンパ節腫大症例, 非腫大症例両方の CT 画像に対し て, 本ソフトウェアを用いて縦隔リンパ節領域分けを 行ったところ, 定義に沿った領域分けが行えることが確 認され，また再現性も概ね良好であった。 しかし，リン パ節領域の境界面の大半を縦隔の腹側・背側辺縁が占め る＃1, \#3a, \#3p については, マニュアル操作を含んで 縦隔を抽出するため, 他の領域に比べて再現性が低い傾 向があった。

もちろん外科医は切除するリンパ節領域については詳 細な認識ができており, CT 撮影時の仰臥位と手術時の 側臥位では軟部組織であるリンパ節領域の形状は異なる ことも予想されるため, 本ソフトウェアにより領域分け 画像を提示することは術中支援画像としては不要かもし れない. しかし，リンパ節領域の共通認識のための教育 ツールとして，またCT 画像に重ね合わせた診断支援画 像や, リンパ節領域の体積計測ツールとしては有用と思 われる. 今後は, 処理の自動化を進め, 精度・再現性の 向上に努めたい.さらに，現在は入力データとして造影 データが対象であるが, 今後は非造影データにおいても 適用できるよう改良を進めていく予定である.

\section{肺区域領域分けソフトウェア}

\section{i) 利用目的}

早期肺癌の標準療法は肺葉切除である 5,6 が, 近年本邦 では, ヘリカル CT の広汎な普及やマルチスライス CT の出現とともに，これまで捉えられなかったきわめて早 期の肺癌が数多く発見されるようになり，それに対する 根治を目的とした縮小手術が再び見直され, $13,142 \mathrm{~cm}$ 以 下の小型肺癌に対しては, 患者の肺機能温存のために区 域切除などの縮小手術が行われるようになってきた. 15 さらに, 肺葉切除術と区域切除術では術後 5 年生存率は 同程度であるとの報告もある. 15 解剖学的に亜区域静脈 が肺区域の間を走行する 16,17 という特徵から，区域間の 境界は亜区域静脈から仮想される面と定義されている. 

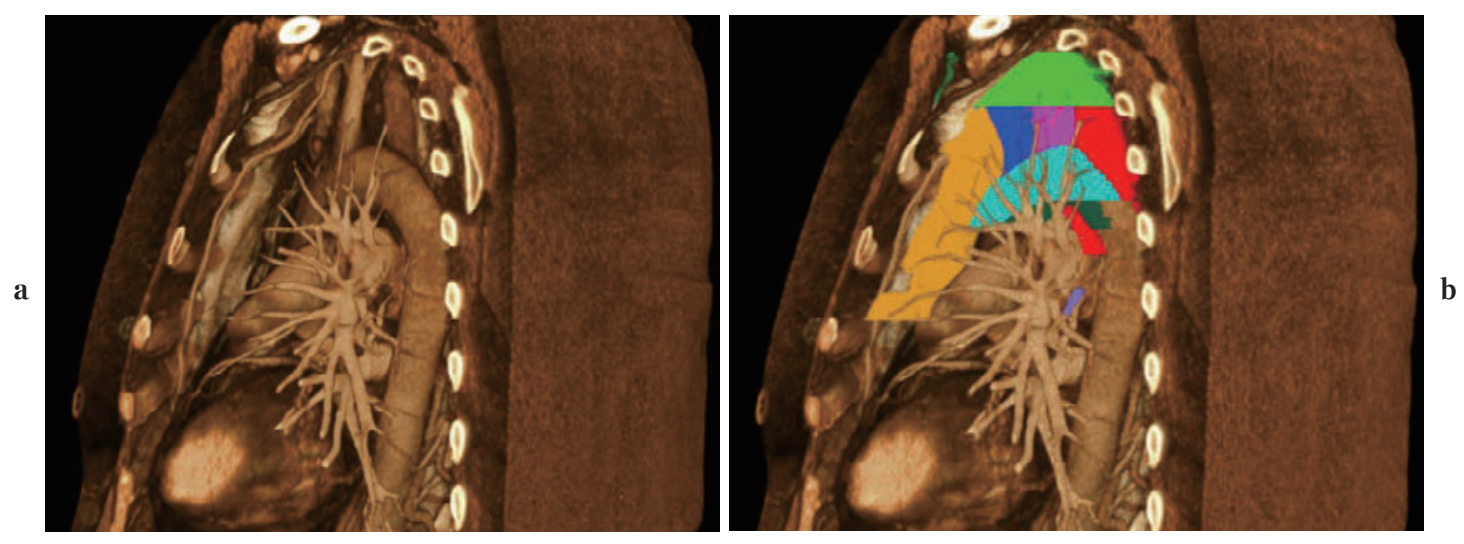

Figure 1. Mediastinal space image (a) was divided into mediastinal lymph node stations (b).

Table 1. Pulmonary Segment in Surgery

\begin{tabular}{|c|c|c|}
\hline Lung lobe & Pulmonary segment in surgery & Subsegmental vein \\
\hline Right upper lobe & $\begin{array}{l}\text { apical segment }\left(\mathrm{S}^{1}\right) / \\
\text { posterior segment }\left(\mathrm{S}^{2}\right) / \\
\text { anterior segment }\left(\mathrm{S}^{3}\right)\end{array}$ & $\begin{array}{ll}\mathrm{V}^{1} \mathrm{~b} & \left(\mathrm{~S}^{1} \text { and } \mathrm{S}^{3}\right) \\
\mathrm{V}^{1} & \left(\mathrm{~S}^{1} \text { and } \mathrm{S}^{2} \text { and } \mathrm{S}^{3}\right) \\
\mathrm{V}^{2}{ }_{\mathrm{a}} & \left(\mathrm{S}^{1} \text { and } \mathrm{S}^{2}\right) \\
\mathrm{V}^{2}{ }_{\mathrm{c}}\left(\mathrm{S}^{2} \text { and } \mathrm{S}^{3}\right)\end{array}$ \\
\hline Right lower lobe & $\begin{array}{l}\text { superior segment }\left(\mathrm{S}^{6}\right) / \\
\text { basal segment }\left(\mathrm{S}^{7-10}\right)\end{array}$ & $\begin{array}{l}\mathrm{V}^{6} \mathrm{~b}\left(\mathrm{~S}^{6} \text { and } \mathrm{S}^{8}\right) \\
\mathrm{V}^{6}{ }_{\mathrm{c}}\left(\mathrm{S}^{6} \text { and } \mathrm{S}^{10}\right)\end{array}$ \\
\hline Left upper lobe & $\begin{array}{l}\text { apicoposterior and anterior segment }\left(\mathrm{S}^{1+2,3}\right) / \\
\text { lingular segment }\left(\mathrm{S}^{4+5}\right)\end{array}$ & $\begin{array}{l}\mathrm{V}^{3}{ }_{\mathrm{a}}\left(\mathrm{S}^{3} \text { and } \mathrm{S}^{4}\right) \\
\mathrm{V}^{3}{ }_{\mathrm{b}}\left(\mathrm{S}^{3} \text { and } \mathrm{S}^{4}\right)\end{array}$ \\
\hline Left lower lobe & $\begin{array}{l}\text { superior segment }\left(\mathrm{S}^{6}\right) / \\
\text { basal segment }\left(\mathrm{S}^{8-10}\right)\end{array}$ & $\begin{array}{l}\mathrm{V}^{6}{ }_{\mathrm{b}}\left(\mathrm{S}^{6} \text { and } \mathrm{S}^{8}\right) \\
\mathrm{V}^{6}{ }_{\mathrm{c}}\left(\mathrm{S}^{6} \text { and } \mathrm{S}^{10}\right)\end{array}$ \\
\hline
\end{tabular}

a

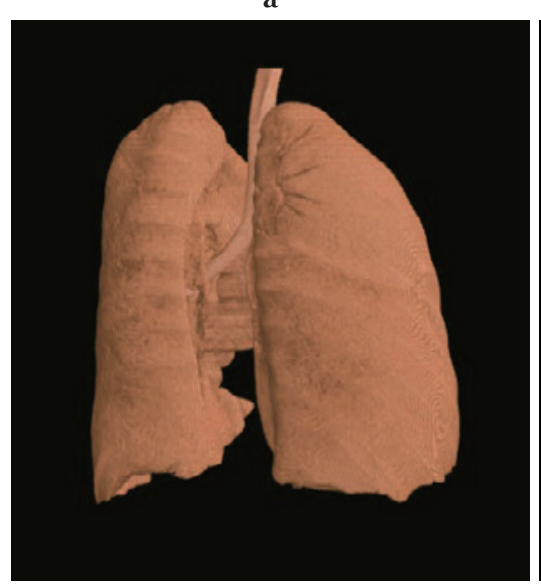

b

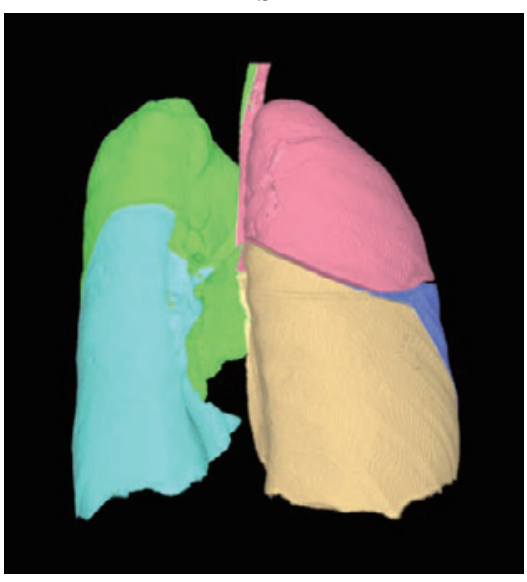

c

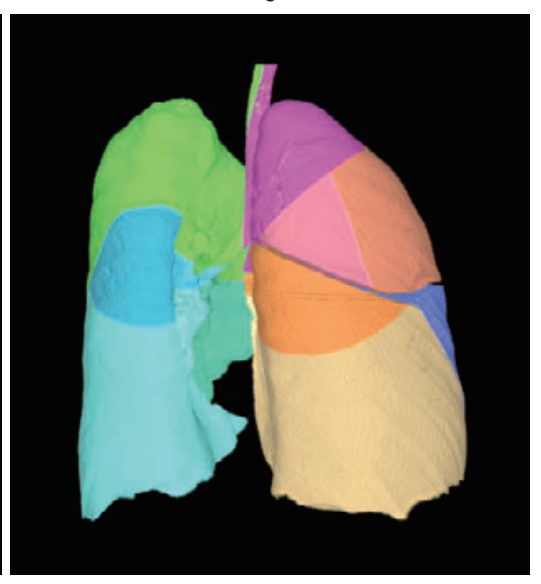

Figure 2. Lung mask image (a) was divided into lung lobes using interpolated fissures (b), and lung lobe image (b) was divided into pulmonary segment using traced particular subsegmental vein data（c).

区域切除術において，術者は電気メスなどを用いて亜区 域静脈, 静脈, 気管支の順に露出させ, 区域間境界面上 を走行する亜区域静脈に沿って目的区域を切除す
る.17-19 区域間の境界面決定には熟練した技術が必要で あるため, 術前に切除区域と周辺血管の位置関係や区域 切除後の呼吸機能の把握を行うことは, 手術支援情報と 
して有用である. 今後縮小手術を一般化させるためは, 区域切除術前のシミュレーションや区域毎の呼吸機能の 推定のために肺区域領域分けを行うことが重要と思われ る.

\section{ii）ソフトウェア概要}

本ソフトゥェアは区域の解剖学上の定義であり,16 区 域切除術の際に術者が区域境界面の指標として用いる亜 区域静脈を用いて区域間の境界面を仮想し，区域毎の領 域分けを行うものである。ここで，本ソフトウェアの利 用目的が区域切除術支援であることから，分割される区 域は, 実際の肺区域（右 10, 左 8 区域）のみではなく, 手術の際に切除する領域（右 6 , 左 4 区域, Table 1）毎 に分割が行えるものとした．以下，手術の際に切除する 領域 (Table 1) 毎の分割操作について説明する. 入力デー タには全肺 CT 画像を用い, Virtual Place (ver.2.03, Office Azemoto Ltd, Tokyo, Japan) のプラグインとして Visual Studio.NET $2003 \mathrm{C}++$ (Microsoft Corporation) に より開発した。

処理の概要は以下の通りである。まず，葉間裂が面構 造であることから，面成分を強調するフィルター17を用 い, 葉間裂を抽出し, これを用いて肺葉毎の分割を行う. 続いて, 操作者が領域分けの対象となる区域間の亜区域 静脈（Table 1) を選択，抽出する．抽出した血管情報は $\mathrm{CT}$ 画像上の位置座標の集合として保存される. $18 こ の$ 亜区域静脈の位置座標を入力データとして Thin Plate Spline (TPS) により補間したなめらかな曲面 19 を肺区域 間の境界面とし，区域間の分割を行う。この際，亜区域 静脈の抽出が不完全な領域については, TPS を用いると 安定した境界面が作成できないため, 抽出血管座標の始 点と終点を結んだべクトルを用いて平面を作成し，境界 面とすることも可能とした。作成した境界面を用いて区 域切除術の際に切除される領域毎にラベル付けを行い, 領域分け表示したものを Figure 2 に示す.

\section{iii）現状と今後の展望}

肺癌術前症例に対して，本ソフトウェアを用いて区域 分けを行った結果，目視により概ね正確な領域分けが行 えることが確認され，マニュアル操作は亜区域静脈の選 択のみであることから，非常に高い再現性が得られた。 しかし，区域間の境界面の正確性は選択する亜区域静脈 に依存するため, 誤った静脈を選択すると, 境界面も不 正確なものとなってしまう。亜区域静脈の選択は外科医 や放射線医といった熟練者でなければ困難であり，ソフ トウェア製作者と熟練者ではソフトウェア製作者の方が 血管の誤選択率が高かった。したがって, 本ソフトウェ アのユーザーとしては外科医や放射線医を対象と考え る。 今後は亜区域静脈の自動選択や，より正確な区域間 境界面作成を行っていく予定である。

\section{まとめ}

画像撮影・撮像技術の進歩により, 多くの診断支援画 像，手術支援画像作成のアルゴリズムやシステムが開発 されている，肺癌診療においては，特に画像診断の果た す役割が大きく，医師と患者両者の負担軽減のために支 援画像技術は重要であり，今回 2 つのソフトウェアを紹 介した。しかし，実際に臨床現場で利用可能なものを作 成するためには医師と製作者との連携が不可欠である. 本稿を医用画像処理アルゴリズムの益々の臨床応用に少 しでも役立てて頂ければ幸いと考える．

謝辞 : 今回御助言を頂いた外科医，放射線医の先生方と大阪 大学大学院医学系研究科医用工学講座画像解析学分野の皆粎 に心から感謝する.

\section{REFERENCES}

1. がんの統計編集委員会. がんの統計'2003. 2003:37.

2. Kuroishi T, Hirose K, Tominaga S, Ogawa H, Tajima K. Prediction of future cancer mortality in Japan. Jpn J Clin Oncol. 1992;22:365-369.

3. Cahan WG. Radical lobectomy. J Thorac Cardiovasc Surg. 1960;39:555-572.

4. 櫻井裕幸, 進藤俊哉, 松本雅彦. 上葉発生肺癌におけるリ ンパ節転移様式と選択的縦隔リンパ節郭清の妥当性に関 する検討. 肺癌. 2005;45:711-716.

5. 渡辺俊一. 肺癌に対する根治手術一肺葉切除とリンパ節 郭清一. 肺癌. 2006;46:15-21.

6. Mori K, Hasegawa J, Suenaga Y, Toriwaki J. Automated anatomical labeling of the bronchial branch and its application to the virtual bronchoscopy system. IEEE Trans Med Imaging. 2000;19:103-114.

7. 目加田慶人, 田中友章, 村瀬 洋, 長谷川純一, 鳥脇純一 郎, 尾辻秀章. 血管と気管支の空間的配置特徵に基づく胸 部 $\mathrm{X}$ 線 $\mathrm{CT}$ 像からの肺動脈・肺静脈自動分類（画像処 理 ・解析, <特集 $>$ 画像の認識・理解論文). 電子情報通 信学会論文誌. D-II, 情報・システム, II一パターン処理. 2005;J88-D-II:1412-1420.

8. 菅原智明, 森 健策, 目加田慶人, 長谷川純一, 鳥脇純一 郎. 3 次元胸部 X 線 $\mathrm{CT}$ 像における縦隔リンパ節の存在 位置の推定. 電子情報通信学会, 医用画像研究会資料. 2002;5:25-30.

9. Chapet O, Kong FM, Quint LE, Chang AC, Ten Haken RK, Eisbruch A, et al. CT-based definition of thoracic lymph node stations: an atlas from the University of Michigan. Int J Radiat Oncol Biol Phys. 2005;63:170-178.

10. Mountain CF, Dresler CM. Regional lymph node classification for lung cancer staging. Chest. 1997;111:1718-1723.

11. Naruke T, Suemasu K, Ishikawa S. Lymph node mapping and curability at various levels of metastasis in resected lung cancer. J Thorac Cardiovasc Surg. 1978;76:832839.

12. 画像診断分類. 肺癌取扱い規約. 日本肺癌学会, 編集. 改 訂第 6 版. 東京：金原出版；2003:12-15. 
13. Tsubota N, Ayabe K, Doi O, Mori T, Namikawa S, Taki $\mathrm{T}$, et al. Ongoing prospective study of segmentectomy for small lung tumors. Study Group of Extended Segmentectomy for Small Lung Tumor. Ann Thorac Surg. 1998;66:1787-1790.

14. Kodama K, Doi O, Higashiyama M, Yokouchi H. Intentional limited resection for selected patients with T1 N0 M0 non-small-cell lung cancer: a single-institution study. J Thorac Cardiovasc Surg. 1997;114:347-353.

15. Wiener DC, Argote-Greene LM, Ramesh H, Audisio RA, Jaklitsch MT. Choices in the management of asymptomatic lung nodules in the elderly. Surg Oncol. 2004;13:239248.

16. Yamashita H. Roentgenologic Anatomy of the lung. Tokyo:
Igaku-Shoin; 1978:39-45.

17. Sato Y, Nakajima S, Shiraga N, Atsumi H, Yoshida S, Koller $\mathrm{T}$, et al. Three-dimensional multi-scale line filter for segmentation and visualization of curvilinear structures in medical images. Med Image Anal. 1998;2:143-168.

18. 山本宗主, 桝本 潤, 堀 雅敏, 佐藤嘉伸, 村上卓道, 中 村仁信, 他. 近傍濃淡情報を用いた分岐点解析による肝臓 CT 画像からの血管 3 次元木構造の抽出手法（ポスター 1 , 医用画像一般). 電子情報通信学会技術研究報告. MI, 医用画像. 2006;105:57-60.

19. Takagi M, Shimoda H. Handbook of Image Analysis. Revised Edition. Tokyo: University of Tokyo Press; 2004:14231434. 